\title{
“There was something very peculiar about Doc...": Deciphering Queer Intimacy in Representations of Doc Holliday
}

\author{
Alex Tankard* \\ Department of English, University of Chester, Chester, UK
}

(Received 26 February 2013; accepted 17 September 2014)

\begin{abstract}
:
This essay discusses representations of male intimacy in life-writing about consumptive gunfighter John Henry "Doc" Holliday (1851-1887). I argue that twentieth-century commentators rarely appreciated the historical specificity of Holliday's friendships in a frontier culture that not only normalized but actively celebrated same-sex intimacy. Indeed, Holliday lived on the frayed edges of known nineteenth-century socio-sexual norms, and his interactions with other men were further complicated by his vicious reputation and his disability. His short life and eventful afterlife exposes the gaps in available evidence - and the flaws in our ability to interpret it.

Yet something may still be gleaned from the early newspaper accounts of Holliday. Having argued that there is insufficient evidence to justify positioning him within modern categories of hetero/homosexuality, I analyze the language used in pre-1900 descriptions of first-hand encounters with Holliday to illuminate the consumptive gunfighter's experience of intimacy, if not its meaning.
\end{abstract}

Keywords: frontier; homosocial; queer; Doc Holliday; tuberculosis

\section{Introduction}

In 1887, notorious gunfighter Dr John Henry Holliday died of tuberculosis in a

Colorado health resort at the age of 36 . Obituaries struggled to make sense of his reputation: a devious gambler who selflessly risked his life for his friends; a frail, exquisitely-dressed "consumptive" invalid reputed to be the most prolific killer on the frontier. Lee Smith, who may have known Holliday since boyhood, recalled "[h]e was a warm friend and would fight as quick for one as he would for himself."1 A Denver obituary reprinted in New York declared "few men of his character had more friends or stronger champions [...] He was a rather good-looking man, and his coolness and

\footnotetext{
*a.tankard@chester.ac.uk
} 
courage, his affable ways and fund of interesting experiences won him many admirers." His devotion to male friends was his most remarkable virtue. But what was the nature of that devotion?

This question is difficult to answer. Biographer Gary Roberts noted that " $[\mathrm{t}] \mathrm{he}$ Doc Holliday of history is an individual seen almost entirely through the eyes of others." ${ }^{3}$ His personal letters have been destroyed, and he even lived under a false name at times, making his movements and motivations difficult to trace. ${ }^{4}$ Few biographical facts survive, suggesting much and proving nothing about his relationships with men or women. Contemporary newspaper accounts are notoriously inaccurate, and their comments about Holliday's relationships are quite opaque to readers outside his milieu.

Influential twentieth-century writers generally insisted Holliday's relationship with Wyatt Earp (1848-1929) was inexplicable. Determined to depict the men as extreme polar opposites - Earp the heroic lawman, and Holliday the amoral, vicious killer - writers like "Bat" Masterson and Stuart Lake created an unlikely pairing that demanded explanation. In the 1930s, Lake's biography of Earp referred to "that extraordinary association of Doc Holliday with Wyatt Earp, which has long been cited as an enigmatic wonder of the Old West." ${ }^{, 5}$ Yet, having created this enigma, these texts were excruciatingly coy and evasive about why these supposedly mismatched men were so drawn to one another.

Until Andrew C. Isenberg's 2009 essay “The Code of the West,” historians did not ask queer questions about Holliday explicitly, but novelists and filmmakers have been less shy about filling the narrative vacuum with homoeroticism. ${ }^{6}$ In Peter Hamill's screenplay for the movie Doc (1971), Earp asks Holliday to leave his mistress and run off with him because "I don't want to sound like a nance, but [...] 
maybe men love each other better than men love women, or vice-a-versa." ${ }^{, 7}$ Walter Satterthwaite's novel Wilde West (1991) depicts Holliday seducing Oscar Wilde and, in 2012, Dale Chase published a gay erotic novel called Wyatt: Doc Holliday's Account of an Intimate Friendship.

Why does Holliday attract such stories? It is, perhaps, surprising to find no hints of homoerotic - or even "enigmatic" - relationships in the earliest representations of Holliday. Were Holliday's contemporaries afraid to admit to queer relationships, or unable to articulate same-sex desire? Or have filmmakers and novelists misinterpreted the historical figures on which their stories are supposedly based?

Researchers including Richard Stott, E. Anthony Rotundo, William Benemann, and Chris Packard have illuminated various cultures of male-male intimacy in nineteenth-century America, and Isenberg demonstrated that the life of Wyatt Earp exemplified a broader shift from homosocial to heterosocial relationships in the 1880 s. However, Earp's most famous male companion never quite fits within the parameters of these studies. A disabled man, raised in a middle-class Southern family, spending much of his adult life in a semi-criminal homosocial frontier subculture, Holliday lived on the frayed edges of nineteenth-century socio-sexual norms. His short life and eventful afterlife exposes the gaps in available evidence and the flaws in our ability to interpret it.

Twentieth-century biographies (including memoirs written by people who had known Holliday) underestimated the historical specificity of his experiences of malemale intimacy, and their use of hostile or facetious language may indicate that they imposed a jumble of later social expectations and psychosexual discourses retrospectively. Yet suspicions of Holliday as a potentially queer figure are not 
altogether a product of twentieth-century homophobia nor ahistorical misinterpretation: even pre-1900 accounts described a "peculiar," out-of-place creature. ${ }^{8}$ When close homosocial friendships were the norm in this predominantly male frontier population, why did Holliday's contemporaries comment upon his relationships? Why did journalists enthuse over his beautiful clothes and feminine hands? What was so "peculiar" about Doc Holliday?

Strangely, the answer to this question may lie not in discourses of sexuality but in his contemporaries' unease about Holliday's physical presence. The final part of this essay analyses the earliest first-hand accounts of personal encounters with "this mild-mannered frontier angel." ${ }^{99}$ Holliday was a legend even during his lifetime, and the fantastical fabrications in contemporary sources mean that he was always more a figure of literature than of historical fact. However, while it may be impossible to locate Holliday within modern concepts of hetero/homosexuality, the nuances of characterization in these texts can illuminate the ways in which Holliday's delicate consumptive body and his deliberate, performative traits (dress, voice and mannerisms) affected his interactions with other men. Whatever the nature of Holliday's relationships, they must have begun with the delicate emotional and tactile negotiations revealed in these texts.

\section{A brief biographical outline}

John Henry Holliday was born in Georgia in 1851, the only surviving child of wealthy middle-class parents. His father Henry was a Confederate officer, and his mother Alice Jane was a chronic invalid; she died in 1866, most likely of tuberculosis, and Henry remarried only a few weeks later. 
Despite hints of a troubled adolescence, Holliday graduated from the Pennsylvania School of Dental Surgery in 1872 and returned to practice in Georgia. He was close to his cousin Martha Anne Holliday, and some historians believe they were in love. ${ }^{10}$ Holliday probably became ill with consumption in $1873 .{ }^{11} \mathrm{He}$ moved to Texas - whether seeking a healthier climate, or unable to face this shift in fortunes under the scrutiny of his successful family, or already in trouble with the law - and never returned. ${ }^{12}$ Martha Anne never married: she entered a convent in 1883.

Holliday spent 14 years moving around the West, eventually abandoning dentistry for the life of a professional gambler. He met Wyatt Earp in Texas in 1877, joining him in Dodge City, Kansas, and then in Arizona in 1879. Earp was an effective (though occasionally brutal) policeman. A handsome young widower, he lived with his brothers or with Mattie Blaylock, and began to court actress Josephine (also known as Sadie) Marcus in the early 1880s. ${ }^{13}$ Meanwhile, Holliday lived intermittently with prostitute Mary Katherine Harony (1850-1940) - also known as Kate Fisher, Kate Elder, or "Big Nosed Kate."14 Given that Holliday described himself as "single" in the 1880 census (and head of a household containing two older men), it is unclear whether this was some kind of unofficial, flexible "marriage," or if he was her pimp, or if their relationship was cordially casual before their permanent separation in $1881 .^{15}$

Holliday stood beside Wyatt and his brothers Virgil and Morgan Earp at the famous gunfight near the OK Corral in Tombstone in 1881, where Holliday committed his only proven act of homicide. Morgan was murdered in 1882, and Holiday joined Wyatt on his bloody vendetta, after which they fled to Colorado and were catapulted into notoriety by the national press. When Holliday was arrested in Denver, facing possible extradition to Arizona, Virgil told a reporter "there was 
something very peculiar about Doc. He was gentlemanly, a good dentist, a friendly man, and yet outside of us boys I don't think he had a friend in [Arizona] territory."16 Virgil may have been exaggerating Holliday's isolation to raise concerns about his safety, but Holliday's peculiarity (in whatever sense of the word) is harder to explain.

Holliday and Earp parted at the end of that summer, Earp moving to California while Holliday remained in Colorado. Despite his reputation, Holliday seems to have increasingly shied away from violence but, in 1884, William Allen threatened to beat him over a $\$ 5$ debt, and Holliday shot and injured him badly. ${ }^{17}$ This was his last gunfight. His health broken by years of tuberculosis and alcoholism, Holliday settled in the resort of Glenwood Springs in 1887, where he died on 8 November, nursed by friends and hotel staff. They discovered he had been corresponding with Martha Anne until the end. ${ }^{18}$

Surprisingly, I can locate only one direct quotation in which Holliday discussed his relationship with Earp. When asked in 1882 whether he was "acquainted with the Earps," Holliday replied "Yes; we are friends."19 Journalist E. D. Cowen, who liked Holliday, later recalled he was "too earnest in his friendships to make a display of them." 20

The most famous (and quoted) descriptions of the relationship from Earp's viewpoint - “How I Routed a Gang of Arizona Outlaws” (1896), and first-person narratives in Lake's Wyatt Earp: Frontier Marshal (1931) - do not seem to have really been dictated by Earp. ${ }^{21}$ However, in two unrelated court appearances, Earp made clear statements about his relationship with Holliday. In 1881, he read a statement declaring "I am a friend of Doc Holliday because, when I was city marshal of Dodge City, Kansas, he came to my rescue and saved my life when I was surrounded by desperadoes." 22 In 1925, Earp told the court that his political rivals in 
Tombstone exaggerated Holliday's crimes because they “knew that I was Holliday's friend and they tried to injure me every way they could."23 Earp also seems to have been quoted directly in an 1893 interview in which he described the aftermath of a gunfight: "Holliday came up to me and caught me gently by the arm. "I'll help you from your horse, Wyatt," he said. "You must be shot all to pieces."24 This suggests their relationship could be affectionate in extreme circumstances, but Earp makes no further remark.

The curt, offhand comments made by Holliday and Earp themselves lay no foundation for the emotional intensity (and graphic eroticism) that would inspire novelists like Chase. Has their friendship been distorted retrospectively, or was there more to it than either man was willing to admit?

\section{From nineteenth-century homophilia to twentieth-century homosexuality}

Throughout Holliday's lifetime, young men on the frontier were expected to form close emotional bonds with each other, perhaps having sex with female prostitutes occasionally, then marrying in their thirties if women were available. ${ }^{25}$ Intimate physical contact between males was not uncommon or discouraged; Chris Packard's Queer Cowboys (2005) reproduces original photographs of frontiersmen holding hands, entwining their legs, bathing naked together, and dancing in a close embrace. ${ }^{26}$ Fiction could depict men falling in love, keeping house, and raising children together, without provoking revulsion or anxiety from other characters in the text or among reviewers. ${ }^{27}$

Yet, when Holliday died, American cultures of same-sex intimacy were beginning to change. David M. Halperin explains that emerging psychosexual discourses associated same-sex attraction with "perverted or pathological 
[psychological] orientation" and "sexually deviant behavior," generating a new category of person: "the homosexual." ${ }^{28}$ Bert Hansen analyzes early studies published in America (albeit only in specialist psychiatric journals) during Holliday's lifetime and, a few years after Holliday's death, Havelock Ellis and John Addington Symonds developed characterizations of the homosexual subject further: ${ }^{29}$

There is a distinctly general, though not universal, tendency for sexual inverts to approach the feminine type, either in psychic disposition or physical constitution or both. I cannot say how far this is explained by the irritable nervous system and delicate health which are so often associated with inversion. ${ }^{30}$

This early characterization of "the homosexual" as an effeminate, sickly "sexual invert" reflected pervasive nineteenth-century anxieties about American manhood being undermined by feminine influences, and assumptions that even same-sex desire still required some kind of binary opposition. ${ }^{31}$ According to Fred Fejes, the "fairy" continued to embody male homosexuality in popular culture until World War II. ${ }^{32}$ Alfred Kinsey's 1948 study challenged this popular conflation of same-sex desire with gender deviance, and ideas of "the homosexual" evolved to include both participants in a same-sex relationship, "whether active or passive, whether gendered normatively or deviantly." ${ }^{33}$ Halperin emphasizes that this "relatively recent and culturally specific development $[\ldots]$ has left little trace in our consciousness of its novelty." ${ }^{34}$ Thus, in addition to pathologizing men who desired men as a deviant "type," commentators across the twentieth-century quickly forgot that same-sex attraction had very different meanings for previous generations.

Just as intense male-male friendships became questionable at the end of the nineteenth century, appealing alternatives became available: the gender imbalance on the frontier decreased considerably between 1880 and 1900, and unchaperoned mixed-sex socializing became commonplace. ${ }^{35}$ Stott observes that "[p]hotographs of 
men holding hands and embracing became less common" and, according to Isenberg, "[i]n this new heterosocial world, men who preferred close companionship with other men - something perfectly ordinary a half-century earlier - came to be regarded as deviant." 36

There is not enough evidence to show precisely how this cultural transition affected Holliday, but changes in tone and language in texts between 1880s texts and post-1900 texts may indicate the influence of those changes on those who outlived him. In 1887, Holliday's obituary in the Leadville Chronicle declared:

whatever faults he had, there beat beneath his bosom the most generous impulses. There is scarcely one in the country who had acquired a greater notoriety than Doc Holliday, who enjoyed the reputation of having been one of the most fearless men on the frontier, and whose devotion to his friends in the climax of the fiercest ordeal was inextinguishable. It was this, more than any other faculty, that secured for him the reverence of a large circle who were prepared on the shortest notice to rally to his relief. ${ }^{37}$

Holliday's devotion to his friends is described in ecstatic terms, but it is obviously socially acceptable and reciprocated, for the reporter willingly imagines intimacy with Holliday, delving "beneath his bosom" to examine his beating heart. Newspapers across America carried an obituary emphasizing Holliday's "coolness and courage," "strong friends," "stronger champions," and "strong character." 38 In the 1880s, Holliday's same-sex friendship was presented as a powerful masculine virtue, seemingly uncomplicated by suspicions of effeminate sexual inversion or deviance. Wyatt Earp is not even mentioned as a special object of affection.

In texts produced after 1900 , the language changes. Sometimes the contrast can be made quite directly. In an 1886 interview, fellow gunfighter "Bat" Masterson emphasized Holliday’s trustworthiness, gentleness, and “convivial nature."39 
However, in a 1907 essay that influenced many subsequent writers, Masterson declared Holliday was a "weakling” and a violent drunk; furthermore, Holliday’s

whole heart and soul were wrapped up in Wyatt Earp and he was always ready to stake his life in defense of any cause in which Wyatt was interested. [...] Damon did no more for Pythias than Holliday did for Wyatt Earp. [...] Holliday had few real friends anywhere in the West. He was selfish and had a perverse nature. ${ }^{40}$

According to Isenberg, contemporaries would read Masterson's allusion to the Classical story of Damon and Pythias as a code for brotherhood or "romantic samesex friendship. ${ }^{41}$ However, this noble allusion is tainted because Masterson places it in the context of Holliday's general perversity, weakness, and inability to form other attachments. The language makes Holliday's infatuation with Earp sound strangling and unhealthy, differing remarkably from the 1886 characterization. ${ }^{42}$

Earp's wife Josephine did not publish her impressions of Holliday during his lifetime, but her 1938 memoir criticized him in terms that resemble Masterson's. She stated that "Wyatt's loyalty to the irascible tubercular [Holliday] was one of gratitude not unmixed with pity." 43 Earp's pity for the diseased "tubercular" adds emotional texture to their relationship but invalidates it as embarrassingly unequal, and Roberts suggests that Josephine was emphasizing her husband's charitable nature at Holliday’s expense. ${ }^{44}$ Her account of their last meeting in 1886 continues to pathologize Holliday. Referring to the C. Lee Simmons/ Mark Boardman copy of the typescript, I have italicized phrases absent from another version of the memoir published privately by Earl Chafin in 1998, and will discuss those omissions below:

I have never seen a man exhibit more pleasure at meeting a mere friend than did

Doc. He had heard that Wyatt was in town, he said, and had immediately looked him up.

They sat down at a little distance from us and talked at some length, though poor

Doc's almost continuous coughing made it difficult for him to talk. 
Wyatt repeated their conversation to me later.

Doc told Wyatt how ill he had been, scarcely able to be out of bed much of the time.

"When I heard you were in Denver, Wyatt, I wanted to see you once more," he said, "For I can't last much longer. You can see that."

Wyatt was touched. He remembered how Doc [...] risked his own life to extricate Wyatt and for this he had always felt grateful. [...]

"Isn't it strange," Wyatt remarked to him, “that if it were not for you, I wouldn't be alive today, yet you must go first."

Doc came over and chatted with us for a few minutes then he and Wyatt walked away, Doc on visibly unsteady legs.

My husband was deeply affected by this parting from the man who, like an ailing child, had clung to him as though to derive strength from him.

There were tears in Wyatt's eyes when at last they took leave of each other. Doc threw his arm across his shoulder.

"Good-bye old friend," he said. "It will be a long time before we meet again." He turned, and walked away as fast as his feeble legs would permit. ${ }^{45}$

Josephine characterizes the clingy invalid as both pathetic and parasitic. She exploits language of sickness and excess to imply that Holliday's infatuation with Earp distinguishes him from other men. As in Masterson's account, the language of strength and reciprocal devotion in the 1887 obituaries has been tainted - and by people who present themselves as authentic first-hand witnesses.

Influential twentieth-century biographies used remarkably coy language to describe Holliday's relationship with Earp. ${ }^{46}$ Lake insisted on the strangeness of "that extraordinary association of Doc Holliday with Wyatt Earp, which has long been cited as an enigmatic wonder of the Old West and about which so much claptrap of mysterious motive, secret design, and fantastic surmise has developed." ${ }^{47}$ Although Lake's tone is facetious, he labors to keep the "mysterious motive" mysterious, 
raising questions where none needed to be asked. This artificial mystery is reinforced by a fictional "quote" that elaborates on Earp's simple 1881 statement about Holliday saving his life in Dodge: "“"if anyone ever questions the motive of my loyalty to Doc Holliday, there's my answer. In the old days, neither Doc nor I bothered to make explanations; I never was given to such things and in our case they would have been contrary to Doc's sense of decency." 48 The convoluted statement pretends to give a definite answer, only to generate more obscurity and intrigue. Why would explanations be indecent? John Myers Myers's 1955 biography of Holliday also seemed unable to accept a simple emotional connection between these men, stating instead that " $[w]$ hatever the spell was, Doc fell under it. Wyatt may not have been much interested in him, but with all the fabled attraction of a man towards his opposites, Holliday was drawn to Earp." ${ }^{49}$ Myers does not suggest sickness or deviance, but why must the attraction be preternatural?

Memoirists and biographers sometimes handled older sources in ways that suggest mistrust or incomprehension. In Chafin's 1998 edition of Josephine’s memoir, the (admittedly problematic) phrases emphasizing the sickly intensity of "poor" Holliday's infatuation with Earp are absent without ellipses to indicate alteration. ${ }^{50}$ Quoting an 1882 newspaper description of Holliday, Myers omitted the journalist's comments on Holliday's hands being "small and soft like a woman's." 51 Material that might illuminate earlier perceptions of Holliday's sexuality or masculinity is deleted without explanation.

The peculiar editing of some primary sources and the coy, arch tone used by influential biographers like Masterson, Lake and Myers may explain why Holliday's friendship with Earp remains "enigmatic" for novelists or film-makers bound to exploit any narrative cracks for dramatic effect, but not why some modern historians 
perpetuate the mystery. In 2007, Peter F. Blake's study twice marveled at the "unexplainable bond" "that to this day leaves historians and scholars baffled." 52 Jeff Guinn's 2011 study emphasized the inexplicableness of this bond by making assertions about Holliday's unlikeable personality - "paranoid," vindictive, and mentally unbalanced by his life-limiting illness - without offering any evidence. ${ }^{53}$ Despite stating that tuberculosis was not proven to be contagious until 1882, Casey Tefertiller suggested in 1997 that Holliday may have been loyal to Earp because "Earp accepted the tubercular dentist at a time when many people feared the disease and would not think of coming near anyone who had it." ${ }^{\text {, }}$ These writers seem trapped between a suspicion that there was more to Holliday's relationship with Earp than we can see, and a reluctance to explore queer possibilities explicitly.

\section{What was so "peculiar" about Doc?}

To address these possibilities openly is to raise awkward questions about the models of sexuality we can legitimately infer from historic representations of samesex intimacy.

Although he does not argue that Earp's relationship with Holliday was one of them, Isenberg suggests that, on the frontier, "some homosocial friendships were privately sexual as well." 55 Sodomy between people of either sex had been illegal since colonial times, but there is evidence that sex between males did occur in nineteenth-century America, whether from personal preference or as "situational homosexuality" where women were unavailable. ${ }^{56}$ While Holliday's daily proximity to female prostitutes renders "situational homosexuality" irrelevant, he could have tried homosex anyway: his disregard for Victorian sexual propriety is evinced by him living openly (and not very faithfully) with Kate Elder, and he admitted to one 
reporter that he had "deviated from the path of rectitude" more generally. ${ }^{57}$ William Benemann points out that, as it leaves no offspring, "it is difficult to imagine how early American male-male sexuality may be detected except through interpretation of the written word, however ambiguous that word may be." ${ }^{\circ 8}$ Perhaps the early descriptions of Holliday's devotion to male friends, followed by the awkward tone of later biographies, are the ambiguous textual evidence Benemann seeks.

Conversely, queer theorists like Halperin suggest erotic desire is experienced and expressed very differently throughout history. ${ }^{59}$ Thus, homosexual relationships as we know them may not have even been imagined in those cultures, illicit or otherwise. Hansen explains that, although the homosexual subject was being constructed in cosmopolitan cities and European and American medical journals at the end of the nineteenth century, "[i]n the same era $[\ldots]$ the homosexual experiences of many people did not include even a hint of the newer consciousness of being a different sort of person" (i.e. a type of man somehow inherently predisposed to desire sex with other males). ${ }^{60}$ And, to borrow Judith Halberstam's critique of dehistoricised "lesbianism," it makes little sense to suggest that "homosexual" desire could somehow exist before the formation of this homosexual "desiring subject." ${ }^{\prime 61}$ Of course, Holliday was probably aware that males had sex with other males: as a gambler and notorious gunfighter, he spent many nights in jails awaiting bail or trial, and Josiah Flynt saw vagrant boys in the overcrowded cells "made use of by all who care to have them. If they refuse to submit, they are gagged and held down." ${ }^{\prime \prime 2}$ However, unless Holliday was extraordinarily committed to a modern notion that one's sexuality is defined entirely by the sex of one's partner, regardless of age, consent, or gender deportment, why would he imagine connecting (or transferring) such incidents to his friendships with men like Earp? Rather than being an archaic 
manifestation of private or latent "homosexuality," homophilic frontier friendships may have represented a complete, historically-specific form of intimacy in which sexual contact was never even considered.

Rather than clarifying the issue, though, the embryonic status of "the homosexual" in this period presents significant obstacles to interpreting the (frustratingly sparse) evidence of Holliday's private life. Firstly, given that we cannot expect a man of his generation to regard homosex or heterosex as the activities of two separate types of people, Holliday's relationships with women do not make engagement in homosex any more or less likely. The fact that two of his close male companions - Wyatt Earp and Frank Lomeister (1856-1935[?]) - married women is irrelevant for the same reason. ${ }^{63}$

Secondly, while it would be more straightforward to erase concepts of homosexuality from our calculations altogether, some early discourses of "sexual inversion" did overlap with the last years of Holliday's life - and Ellis' notion of a link between inversion and "delicate health" is rather intriguing. ${ }^{64}$ It is possible that some pre-1900 descriptions of Holliday were flirting with these new concerns about men of "the feminine type" whose "dress is always precise and natty, showing more especially in pattern, style and arrangement of necktie a taste and deftliness rarely found in men." ${ }^{65}$ In 1882, the Denver Republican noted that Holliday's "hands are small and soft like a woman's, but the work they have done is anything but womanly." ${ }^{66}$ An 1883 newspaper enthused over "this mild-mannered frontier angel" with his "immaculate" grooming, "beautiful scarf, with an elegant diamond pin in the center," and "beautiful, silver-mounted revolver." ${ }^{\text {"67 }}$ An 1899 newspaper insisted he had "a heart as tender as a woman's," while an 1896 story depicted frontier roughs bullying him for his dandyish dress and cleanliness - only to discover the 
consumptive dentist could "hurl deadly bullets with a hand as beautiful as a woman's." ${ }^{98}$ In 1898 Cowen recalled:

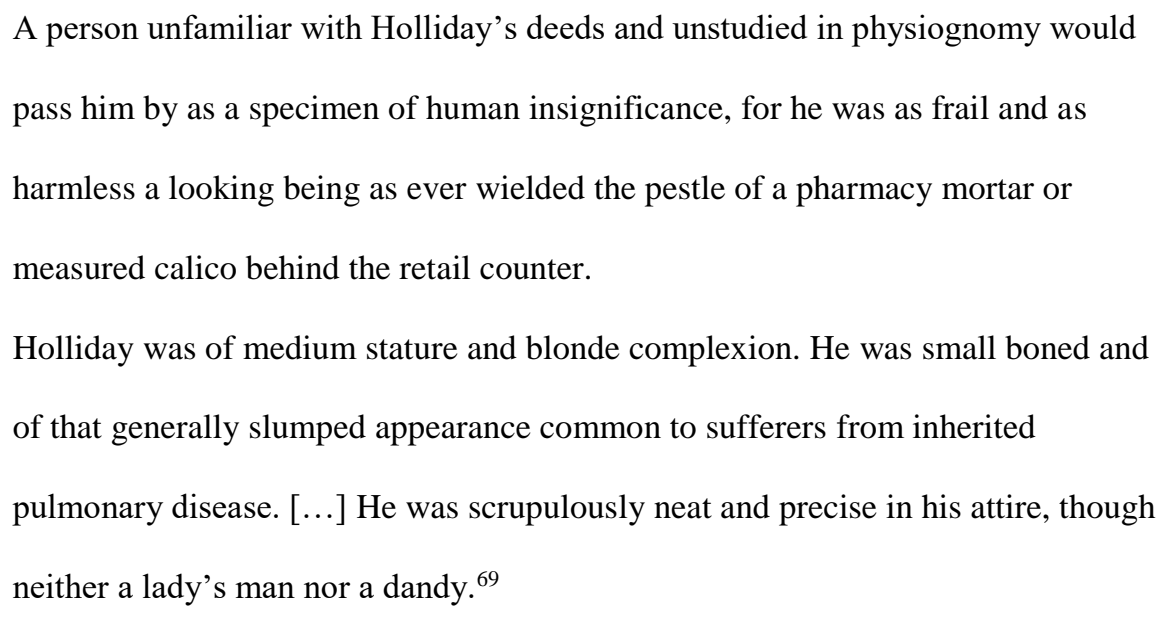

According to Hansen, the timid draper "behind the retail counter" was a byword for unmanliness in 1890s America. ${ }^{70}$ Perhaps Cowen can speak playfully about Holliday's unmanly exterior because his involvement in dueling - the most absolute (and desperate) assertion of manhood available in Holliday's culture - proves he was truly masculine..$^{71}$ Cowen's eagerness to absolve Holliday of frivolous womanizing as “a lady's man" might indicate Cowen is completely unconcerned by (or unaware of) "homosexuality" - although his distinction between the "lady's man" and the "dandy" suggests awareness that some exquisitely-dressed men are not interested in women. ${ }^{72}$ We are assured that, despite appearances, Holliday was neither type.

Early discourses of sexual inversion may have had more influence on Masterson and Josephine Earp - not only in their depictions of Holliday as sickly and clinging but, more revealingly, in their insistence on his unhealthy infatuation with the "hyper-masculine Earp."73 This pairing is not a homosocial friendship between equals but, rather, a gendered binary with erotic potential: according to Ellis in the 1890s, the effeminate invert generally desires men unlike himself. ${ }^{74}$ As Halperin and Rotundo point out, the assumption that both partners in a homosexual couple could be equally masculine (and equally homosexual) is relatively recent. ${ }^{75}$ 
It is possible that Holliday was aware of the earliest discourses of inversion and/ or homosexuality. It is also quite likely that he was not interested in them, and that any hints of "inversion" in 1880s depictions of Holliday are coincidental. The violent, exploitative "homosexuality" Flynt described in American jails in the 1890s bears no resemblance to devoted homophilic friendship between men like Holliday and Earp other than the biological sex of the people involved. Yet, given Holliday's near-silence on the matter, how can we infer anything about the nature of his relationships from the evidence available?

\section{Evaluating Holliday's friendships}

Tallying up Holliday's relationships with men against those with women would not demonstrate any preference - let alone demonstrate whether he had learned to regard such a preference as defining his identity. However, reconstructing a broader pattern of homophilic norms in Holliday's milieu may illuminate what, if anything, about Holliday's relationships was peculiar within his cultural context. In the 1930s, Josephine Earp declared she had "never seen a man exhibit more pleasure at meeting a mere friend than did Doc," and described him putting his arm around Wyatt's shoulders as they parted for the last time. Was this the public face of a "privately sexual" friendship?

The language in 1880s-90s newspaper articles does not suggest that displays of affection between parting male friends were regarded as public façades for “crime[s]-against-nature" occurring behind the scenes. ${ }^{76}$ For example, an 1885 newspaper reported approvingly that actor Herr Sonnenthal "kisses his male friends

good-bye and shakes hands with the ladies. ${ }^{77}$ Before J. R. Birchall was hanged in 1890 for murder he "turned to his friend Leetham and kissed him. Their lips remained 
intact for several seconds and though there was no outburst or any external signs of emotion it was evident to everyone present that the parting was accompanied by the intensest agony."78 The reporters express no disgust or suspicion; nor do they probe these scenes to uncover secret "homosexual" desire straining towards illegal consummation. Had Josephine Earp in the 1930s forgotten that exhibitions of affection were not unique fifty years earlier? Indeed, if Cowen's 1898 recollection was accurate, Holliday was quite undemonstrative by nineteenth-century standards.

One notable peculiarity of Holliday's close bonds with other men is that they continued until his death in early middle-age. Rotundo's analysis of romantic friendships among middle-class men in the nineteenth century suggests that such relationships were characteristic of youth (a period of uncertain career prospects, bachelorhood, and mobility) and ended with maturity, marriage, and career stability. ${ }^{79}$ Isenberg demonstrates that, in the case of Wyatt Earp, this personal development coincided with a broader cultural shift from homosocial to heterosocial intimacy in the $1880 \mathrm{~s} .{ }^{80}$ However, instead of marrying in his thirties, Holliday became increasingly disabled - and died. Given opportunity, would he have married, or would he have defied new social expectations?

Interestingly, in his milieu, violation of these norms was neither unprecedented nor inexplicable. Pre-1900 sources place Holliday firmly within a circle of reciprocal devotion in the saloon demimonde. The gambler community took immense pride in caring for their sick, broke and dying friends. ${ }^{81}$ According to Stott, "Even among married or cohabiting sporting men, their closest emotional relationships often seem to have been with other men. The era of ardent male friendship was passing, but sporting men remained distinctive in their devotion to male comrades." 82 Stott goes on to give the (especially pertinent) example of 
consumptive gambler John C. Heenan who literally died in the arms of his friend James Cusick in 1873. In 1884, thirty-three year-old Holliday was living with bartender Frank Lomeister. Their domestic arrangements are unrecorded but, in overcrowded frontier boomtowns, it was common for roommates to share a bed. ${ }^{83}$ Given Holliday's poverty and debilitating illness at this point, it is possible Lomeister was also supporting him financially and acting as nurse. On the page opposite an article reporting Holliday's trial for shooting William Allen, the Leadville Democrat stated simply: "Frank Lomeister sticketh to his friends closer than a brother." 84 Whatever Lomeister's adhesive devotion (presumably to the hapless Holliday) involved, local readers clearly required no explanation or justification. And again, this devotion was not exclusive. During the Allen hearing, members of the tough saloon demimonde petitioned anxiously to bail Holliday out of jail "as his constitution is badly broken and he has been really sick for a long time past," demonstrating real concern for a man they deemed vulnerable and in need of their protection. ${ }^{85}$ Obituaries reported that Holliday "had some warm friends, who speak of him with tenderness" and, as he lay dying in Glenwood Springs, "[h]is friends in Leadville sent him a purse on Monday morning last, by express," to pay for his care. ${ }^{86}$ These comments locate Holliday (and Lomeister) within a wider circle of supportive friendships deemed worthy of remark but not interrogation, embarrassment, or secrecy.

How deviant was the gambler community? Evidently, involvement in these circles was not necessarily an obstacle to following the social norms described by Rotundo and Isenberg. Like Earp, Lomeister married in his thirties. Lomeister also bears out Rotundo's suggestion that clubs and lodges allowed men to maintain their youthful ideals of male-male devotion, albeit in a depersonalized form. ${ }^{87}$ In the light 
of Masterson's comments about Damon and Pythias, it seems apt (if one ignores the amusing modern connotations) that Lomeister helped organize a "gay dance" for the Knights of Pythias in 1894, and was appointed Deputy Grand Chancellor of a Pythian lodge in $1895 .{ }^{88}$ For Lomeister, loyalty to Holliday was just one phase in a lifelong and very open commitment to noble homophilic ideals that did not cease on marriage but, rather transferred from intense personal relationships in youth to formal, ritualized fraternal organizations in maturity. ${ }^{89}$

Ultimately, none of this tells us whether Holliday's relationships with other men were simply brotherly, or romantic, or wistfully homoerotic, or actively sexual. In his case, what looks like evidence of homosexuality (or, indeed, heterosexuality) is nothing of the kind. It is only clear that the gambler community embraced him very publicly. Two of his close companions followed the patterns described by Rotundo and Isenberg, but diverging from these patterns was also accepted among gamblers who lived unpredictable lives, cared for their sick and helpless in their own way, and celebrated devoted friendship.

\section{"This mild-mannered frontier angel"}

There is another way of examining Holliday's relationships.

In various interviews, Holliday complained that his illness and his deadly reputation complicated his interactions with other men. Pre-1900 descriptions located this complication in his actual physical presence, which elicited subtle, conflicting emotional and tactile responses from those who met him. More than a century after his death, the peculiar experience of meeting the consumptive gunfighter in person can be approached only by analyzing early descriptions as literary texts that reconstruct a character's mannerisms, voice, and physique through nuances of 
language. Instead of attempting to categorize early descriptions of Holliday under modern notions of hetero/homosexuality, I simply take a fresh look at personal reactions to Holliday, his anxieties about intimacy with other men on the violent frontier, and his attempts to manage these encounters.

Following the gamblers' circuit around cattle and mining camps notorious for male-on-male violence, Holliday's interactions with other men were unavoidably tense. In Courtwright's homicide statistics for the 1870s-1880s, Philadelphia (3.2 homicides per 100,000 people annually) may be contrasted with Leadville (105 homicides per 100,000) and Fort Griffin, Texas (a stunning 229 per 100,000). ${ }^{90}$ Yet Holliday's presence in these towns does not necessarily prove he had an insatiable appetite for confrontation: in 1882, he apparently told residents of Pueblo "in conversation $[\ldots]$ that he had never killed any one, except in protecting himself, and that all he asked was to be let alone; he left Arizona with the single purpose of being at peace with every one around him. ${ }^{\text {'91 }}$ Although asking to be "let alone" suggests a desire to repel intimacy, the openness and pathos of his plea makes him seem oddly approachable.

In fact, there is little evidence that Holliday used his (undeserved) reputation as the most prolific man-killer on the frontier to frighten other men into keeping their distance. Rather, he seems to have strenuously downplayed his reputation because he regarded it as not only a product but also a cause of unwanted, hostile interactions: "There are people in [Leadville] who desire to murder me for notoriety. They know I am helpless and have spread the report that I am a bad man, to protect themselves when they do the work. I defy anyone to say they ever saw me conduct myself in any other way than a gentleman should." 92 His convoluted insistence on his gentility and helplessness conveys something like pain at the thought of frightening anyone. This 
persona was evidently convincing, for journalists confirmed that " $[\mathrm{t}] \mathrm{his}$ mildmannered frontier angel, who has started a graveyard in nearly every frontier town that he has graced with his presence, is one of the quietest and most gentlemanly men that I ever met." 93 Another reporter interviewing him in Denver jail admitted " $[t]$ he first thing noticeable about [Holliday] in opening the conversation was his soft voice and modest manners." 94 The traits Holliday projected were the opposite of assertive, and yet the fact of him performing them dominated first impressions and dispelled the journalists' anxiety about his vicious reputation. His forceful, defiant gentleness made him seem approachable even in these tense situations.

Holliday's physical appearance also played a major part in diffusing other men's fear and hostility for, as Cowen explained in 1898, his "inherited pulmonary disease" made him "as frail and as harmless a looking being" as one could imagine. ${ }^{95}$ When he became infamous in 1882, Holliday was 30 years old and had suffered from chronic pulmonary tuberculosis for at least nine years, in an era when most American consumptives did not live past $35 .{ }^{96}$ The symptoms of advanced tuberculosis are physically incapacitating and obvious. At times, Holliday would have suffered overwhelming exhaustion and emaciation. Coughing and breathlessness would become increasingly debilitating as his lungs disintegrated into cavities and scarring. ${ }^{97}$ Holliday was one of around 200,000 American consumptives living at that time and, familiar with what his symptoms meant, his contemporaries found it hard to imagine his involvement in physical violence: his hair was gray at the age of thirty and the Denver Republican marveled that his "slender wrist" could even lift a gun. ${ }^{98}$

Crucially, he looked (and doubtless was) significantly weaker than healthy men, making him an easy target for violent rival gamblers - the type of intimacy he evidently wanted to avoid. ${ }^{99}$ The average weight for a late-Victorian man of 
Holliday's height (5'10”) was 168 pounds but, by 1884, he weighed just 122 pounds. ${ }^{100}$ Little wonder he was described as "a slender man," "a thin, spare man" and, at worst, "a slender, sickly fellow," "emaciated and bent." ${ }^{101}$ During his court hearing for shooting William Allen, who had allegedly threatened to "knock him down and kick his d—n brains out," Holliday explained, "I knew that I would be a child in his hands if he got hold of me; I weigh 122 pounds; I think Allen weighs 170 pounds. I have had the pneumonia three or four times; I don't think I was able to protect myself against him." 102 His painful awareness that he could not control what stronger men might do to him was obviously frightening and humiliating. ${ }^{103}$

Described by one Leadville journalist as "weak, out of health, sprits and money, slowly dying," Holliday complained "with tears of rage" that "I am afraid to defend myself and these cowards kick me because they know I am down." 104 Yet again, Holliday defended himself not by asserting his killer reputation but by presenting himself as a helpless victim. His complaints indicate a peculiar combination of fear and trust of the men around him - a willingness to display his vulnerability as if seeking mercy and protection.

Would anyone sympathize with a consumptive gunfighter? Tefertiller's suggestion that Holliday clung to Earp because others perhaps "would not think of coming near anyone who had [tuberculosis]" demonstrates how misunderstanding historically-specific constructions of disability distorts Holliday's emotional and social experiences. In fact, before the 1890s, "consumption" was seldom described and perhaps not always experienced - as a disgusting disease. Instead, novels like Charles Dickens's Nicholas Nickleby (1839) and Charlotte Bronte's Jane Eyre (1847) romanticized consumptives, and his mother Alice Jane Holliday's 1866 obituary described her debilitating chronic illness as a privileged state of spiritual insight and 
“calm, cheerful, joyful” Christian suffering. ${ }^{105}$ Throughout her son's lifetime, Romantic/religious models of "consumption" were gradually replaced by a new biomedical model analogous with the disease we now call "tuberculosis" but, crucially, he died too soon to suffer the stigma and social rejection that arose with public panic about contagion at the turn of the century. ${ }^{106}$ Although Robert Koch published his discovery of the organism Mycobacterium tuberculosis in 1882, Cowen's 1898 reference to Holliday's “inherited pulmonary disease” indicates Holliday and his friends continued to believe that he inherited his saintly mother's illness, and that he posed no danger to those around him. ${ }^{107}$

Thus, before the emergence of twentieth-century stigma, Holliday's condition could make him a fragile and (in Romantic terms) appealing object of compassion. According to Miriam Bailin, Victorian cultures of invalidism celebrated the sickroom as "a privileged site of untroubled intimacy," and illness as an opportunity for openness and tenderness. ${ }^{108}$ The Leadville gamblers who petitioned for Holliday to be granted bail "as his constitution is badly broken and he has been really sick for a long time past" describe their vivid impressions of a body ravaged and wretchedly vulnerable, but not disgusting. ${ }^{109}$ There are hints that Holliday knew how to encourage their sympathy. His court statement combined emotive allusions to his childlike vulnerability with hard physiological facts about his weight and his pneumonia, using his illness in every possible way to present himself as a helpless victim. ${ }^{110}$ Recalled to court in December, Holliday wore "a huge camel's hair overcoat": given that his clothes were usually "close fitting" and "custom-made," it is possible he borrowed this oversized coat to impress onlookers with his frailty. ${ }^{111}$ Indeed, his elective mannerisms had always emphasized his frail physique; his "quiet, 
modest" speech and "a smile that was child-like and bland" made him seem small and submissive. ${ }^{112}$

Yet if Holliday deliberately enhanced sympathetic responses, he also resented his vulnerability to being handled with uninvited, thoughtless intimacy like "a child." Although Cowen seemed to find Holliday's fragility and fastidiousness endearing, his playful tone carried a hint of ridicule that might, perhaps, turn sour. ${ }^{113}$ Newspapers circulated many comical stories of frontier ruffians humiliating or even killing weaker consumptive men for fun and, although the stories are probably apocryphal, their recurrence suggests that the scenario was considered amusing in some way. ${ }^{114}$ Given Holliday's reliance on goodwill from stronger men, how could he manage their reactions?

This is one of the most "peculiar" aspects of Holliday's interaction with other men. The language used in early descriptions indicates that he worked hard to control intimacy without repelling it entirely, and that people responded with appropriate caution. Some words recur several times. "Quiet" is used in at least five articles (sometimes with multiple uses in one article) to describe his voice and his manners more generally - an elective, performative aspect of his persona - indicating that he was perceived as politely self-contained. ${ }^{115}$ Other descriptions make him seem less approachable: two separate accounts describe him as "scrupulously neat"; the word "polished" is used to describe his boots, his shirt, and his manners; his hair is "silvered" and "frosted." 116 His cleanliness was obviously admired, but its icy, forceful meticulousness seems too sharp and shiny to invite closer intimacy. This peculiar balance between the approachable and unapproachable is exemplified by one word in particular: an 1882 article and two separate witnesses in the 1884 Allen hearing describe him as "delicate."117 Unlike "thin," this dainty, appealing word goes 
beyond the purely visible aspects of Holliday's condition to imply a more profound helplessness, or even brittleness to the touch. As in the description of his "badly broken" constitution, there is an intimacy in imagining another man's vulnerability and an awkward tenderness in acknowledging that his body might break if handled roughly. The Denver Republican went so far as to describe his hands as "small and soft like a woman's," emphasizing not only Holliday's feminine delicacy but also the tenderness this delicacy invited - the opportunity to touch, consider, and then describe what his hands feel like - before admitting that "the work they have done is anything but womanly. ${ }^{118}$ Did the reporter crush these dainty hands, attempting to cow Holliday with a manly handshake? Or did the recollection of their brutal "work" repel him? His appreciation of their smallness and softness suggests instead a far more sensitive negotiation.

Arguably, after Holliday became notorious in 1882, new relationships with men would have to begin with this "peculiar" negotiation. Intimacy could be imagined in detail, even if actual physical contact was sometimes discouraged by his quietness, brittleness, and sharply "polished" appearance. Given the scarcity of surviving evidence about Holliday's private life, descriptions of these encounters can suggest tantalizing details that are more personal and intimate than simply imposing modern categories of sexuality to decide whether they were queer or straight.

\section{Conclusion}

Holliday's relationships with other men continue to elude any single interpretation. Novels and films provide a valuable space in which to imagine aspects of private life that cannot be reconstructed any other way, and there is nothing wrong with such texts filling the emotional void in Holliday's story with homoeroticism or 
any other speculation. More exasperating is the tendency among some non-fiction writers to use suspicious, pathological language that implies a link between same-sex friendship and murky psychological or social deviance, instead of addressing homoerotic possibilities openly or exploring the cultural context in which Holliday formed his relationships.

Pre-1900 texts described Holliday's friendships with enthusiasm and reverence, not coyness or suspicion. What little evidence exists indicates that his experiences of male-male intimacy were celebrated in his milieu. This does not tell us with any certainty what those experiences actually involved. Further research is needed to indicate what expressions of romance or sexuality were tolerated in the gambler community, as existing studies on homosex among nineteenth-century American tramps and sailors are not entirely relevant. ${ }^{119}$

It is unwise to infer that Holliday's relationships were primitive manifestations of repressed "homosexuality." However, one interesting complication lies in the overlap between many traits described in first-hand encounters with Holliday and the earliest accounts of "the homosexual" as an "invert." Cowen's 1898 article comparing Holliday with a draper (but "neither a lady's man nor a dandy") may suggest that Holliday's friends were toying with the possibility of re-evaluating him in those terms before 1900 - if only to dismiss it. The pre-1940s conflation of homosexuality with effeminacy could certainly explain why the delicate, vulnerable Holliday's attraction to Earp was described in unwholesome terms by Masterson and Josephine, while the ultra-masculine Earp was not implicated - that is, until concepts of homosexuality evolved later to include feminine and masculine participants equally. ${ }^{120}$ However, Holliday himself refused - in the most absolute, final way possible - to engage with emerging psychosexual discourses: instead of marrying in the 1880s like Earp and 
Lomeister, taking a clear position in the hetero end of a new hetero/homosexual binary, Holliday died.

Early texts about Holliday also demonstrate that his disability could complicate male intimacy. In a society fraught with male-on-male violence, the consumptive gunfighter was, understandably, anxious about his inability to prevent unwanted physical contact: in 1884, Holliday's intense (and precise) awareness of the difference between their bodies led him to shoot an unarmed man. Yet the vulnerable consumptive body could also inspire special compassion and tenderness.

The greatest mystery about Holliday's intimacy with other men resides in something inaccessible to even the most careful historians. Early descriptions of Holliday indicate that meeting him in the flesh was a remarkable experience that provoked a variety of complex emotions. It is therefore frustrating that his voice, clothes and mannerisms are long gone. The location of his grave has been forgotten, so even his bones have been lost to posterity.

Yet treating first-hand descriptions as literary texts can provide some insight into the reactions Holliday provoked - whether people in this predominantly male society wanted to look at him, be near him, handle or manhandle him. The level of detail and, above all, the tactile language used in these descriptions shows the commentators' willingness to imagine such intimacy. Looking past the twentiethcentury stigma imposed upon tuberculosis is essential: like modern hetero/homosexual binaries, pathologization of "the consumptive" has erased any trace of its novelty. ${ }^{121}$ Far from making him a revolting pariah, Holliday's consumption made him more approachable to his contemporaries, alleviating fear or hostility provoked by his reputation. Even in 1886-1887, when he was extremely sick, two articles still described him as "a rather good-looking man."122 One obituary 
declared: "A fellow of pleasing manner, and very polished in his address, his prematurely frosted locks attracted attention wherever he went." ${ }^{123}$ This attention was sometimes admiring and affectionate. His companions in the saloon demimonde where not shy about expressing their protective impulses; they worried about his heath, gathered money to pay for his care, and were even willing to share their bedroom or their bed with the consumptive gunfighter. Early descriptions evoke a complex, elusive amalgamation of emotional and tactile responses on both sides. Holliday's relationships were not really queer: the only appropriate word is "delicate."

\section{Notes}

1 “A Gritty Georgian,” Macon Weekly Telegraph, February 14, 1888.

2 "Death of a Notorious Bunco Man (from the Denver Republican)," The Sun (New York), November 20, 1887.

${ }^{3}$ Roberts, Doc Holliday, 3.

4 “"Holliday’s Trail of Blood," Denver Republican, December 25, 1887.

${ }^{5}$ Lake, Wyatt Earp, 192.

${ }^{6}$ Roberts, Doc Holliday, does not clarify these issues, but nor does Roberts imply that Holliday's relationships were peculiar within his cultural context.

${ }^{7}$ Hamill, Doc,115-6.

${ }^{8}$ Virgil Earp (interviewed by San Francisco Examiner), Arizona Daily Star, May 30, 1882, Tombstone Historical Society, http://www.tombstonehistoryarchives.com/?page_id=14 (accessed July 29, 2011).

9 “Leadville Sketches," Omaha Daily Bee, May 10, 1883.

${ }^{10}$ Especially Jahns, Frontier World of Doc Holliday.

${ }^{11}$ In “A Gritty Georgian," friends who knew him in Atlanta later guessed his weight as 125 pounds, which suggests that in the early 1870s he was already severely underweight for a man of his height. In "Doc Holliday," Atlanta Weekly Constitution, June 27, 1882, his friend Lee Smith said Holliday was 5'10" tall. According to Squire, Hygienic Prevention of Consumption, 189, the average weight for a man 5'10" was 168 pounds, and companies would not offer life insurance for men under 140 pounds. 
${ }^{12}$ Masterson, "Doc Holliday," 36-38, claims Holliday fled Georgia after killing three AfricanAmerican boys. No documentary evidence exists for this.

${ }^{13}$ Isenberg, "Code of the West:," 148; 152.

${ }^{14}$ A. W. Bork and Glenn Boyer, eds., "Mary Cummings' Statement,” 77; 79.

${ }^{15}$ United States census, 1880: J. H. Holladay [sic], Prescott, Yavapai, Arizona, https://familysearch.org/pal:/MM9.1.1/MH2H-RT3 (accessed August 11, 2012).

${ }^{16}$ Arizona Daily Star.

17 "Doc Holliday's Career," Boston Daily Globe, August 4, 1886. Thanks to Roberts for locating this piece.

18 "Death of J.A. [sic] Holliday," from Riland scrapbook, repr. in Traywick, John Henry, 250. The original newspaper has been lost.

19 “A Man of Sand,” Gunnison News-Democrat, June 18, 1882, repr. in Stephens, ed., Wyatt Earp Speaks!, 365.

${ }^{20}$ E. D. Cowen, "Happy Bad Men of the West: a Reminiscence," Salt Lake Herald, November 14, 1898.

${ }^{21}$ Earp's friend John P. Clum queried Earp's input (and sobriety) for the 1896 piece in a letter to George H. Kelley, August 30, 1929, repr. in Badon, “An Unexpected Nugget,” 24-25. Faragher, "Tale of Wyatt Earp" calls Lake's book "an imaginative hoax, a fabrication.” Lake often pretends to be Earp speaking in the first person.

${ }^{22}$ Statement of Wyatt Earp in the preliminary hearing in the Earp-Holliday case, heard before Judge Wells Spicer, November 16, 1881,

http://law2.umkc.edu/faculty/projects/ftrials/earp/wearptestimony.html (accessed November 29, 2011). No doubt Earp prepared this statement with his attorney, but there is no reason to suppose Earp did not compose it himself; he was certainly willing to read it aloud in court.

${ }^{23}$ Testimony of Wyatt Earp in the 1925 Lotta Crabtree probate trial, Tombstone Historical Society, http://www.tombstonehistoryarchives.com/?page_id=6 (accessed July 29, 2011).

24 "He is a Dude Now," Denver Republican, May 14, 1893.

${ }^{25}$ Isenberg, "Code," 146.

${ }^{26}$ Packard, Queer Cowboys. 
${ }^{27}$ See Stewart-Winter and Stern, "Picturing Same-Sex Marriage in the Antebellum United States" on attitudes in 1830s Georgia. "Miss Harraden's Hero," Washington Times, January 29, 1899, complained about Beatrice Harraden's “California Stories" (1897) - but only about the fact that Harraden depicts frontiersmen wearing spurs indoors.

${ }^{28}$ Halperin, How To, 42-3. In this essay I use "homosex" to denote same-sex sexual activity, without implying anything about the meaning attributed to that activity. I use "homophilic" (adjective) to describe same-sex love - again, without implying anything about the nature of the love. However, I regard "homosexuality" as a late-Victorian medical concept defining a psychologically- or biologically-fixed tendency to experience sexual desire for people of one's own sex.

${ }^{29}$ Hansen, “American Physicians' "Discovery” of Homosexuals, 1880-1900," 15, reproduces details from Blumer, “A Case of Perverted Sexual Instinct (Conträre Sexualempfindung),” 23-25.

${ }^{30}$ Ellis and Symmonds, Sexual Inversion, 192.

${ }^{31}$ Rotundo, American Manhood, 276-78; Ellis, Sexual Inversion, 192.

${ }^{32}$ Fejes, Gay Rights and Moral Panic, 12; Rotundo, American Manhood, 277.

${ }^{33}$ Halperin, How To, 132. See Fejes, Gay Rights, 15, on Kinsey.

${ }^{34}$ Halperin, How To, 3.

${ }^{35}$ Isenberg, "Code," 146-7. See Stott, Jolly Fellows, 255, on the declining gender imbalance Colorado and Arizona between 1880 and 1900.

${ }^{36}$ Stott, Jolly Fellows, 255; Isenberg, “Code,” 146-7.

37 "Death of Doc Holliday," Leadville Chronicle, November 8, 1887.

38 'Death of a Notorious Bunco Man'.

39 “'Doc Holliday's Career'.

${ }^{40}$ Masterson, "Doc Holliday,” 36; 40-2.

${ }^{41}$ Isenberg, "Code," 155.

${ }^{42}$ In private email correspondence (May 16, 2009), Roberts suggested that Masterson's editor Alfred Henry Lewis may have influenced the tone of this article, but the extent of that influence is unclear.

${ }^{43}$ Josephine Earp, in Roberts, Doc Holliday, 366.

${ }^{44}$ Roberts, "Brothers of the Gun," 35. 
${ }^{45}$ Josephine Earp, Mabel Earp Cason, and Vinnolia Earp Ackerman, "She Married Wyatt Earp," c. 1938, unpublished typescript, Mark Boardman/ C. Lee Simmons Collection. This C. Lee Simmons copy is cited by Roberts and Tefertiller.

${ }^{46}$ Burns, Tombstone, 51-2 is an interesting exception, as its florid language still resembles that of the 1880s obituaries.

${ }^{47}$ Lake, Wyatt Earp, 192.

${ }^{48}$ Lake, Wyatt Earp, 215.

${ }^{49}$ Myers, Doc Holliday, 65.

${ }^{50}$ Earp, Wyatt's Woman, 95 . Given the problematic history of this memoir, it is possible Chafin was faithfully reproducing a copy of a manuscript that had been altered by another party - but somebody has made a decision to alter the material at some point.

${ }^{51}$ Quoting Awful Arizona," Denver Republican, May 22, 1882, Myers, Doc Holliday, 179, does use ellipses to indicate that material has been cut. Even Herda, They Call Me Doc, kindle edition, location 1947, omits this part of the description.

${ }^{52}$ Blake, Hollywood and the OK Corral, 2; 7.

${ }^{53}$ Guinn, Last Gunfight, 46.

${ }^{54}$ Tefertiller, Wyatt Earp, 49.

${ }^{55}$ Isenberg, “Code," 146.

${ }^{56}$ See "Opinion of the court in John Geddes Lawrence and Tyron Garner v. Texas, Supreme Court of the United States," 539 US (3003), 7-9, http://www.law.cornell.edu/supct/pdf/02-102P.ZO (accessed January 25, 2011); Flynt, "Homosexuality Among Tramps" ; and Burg, Gay Warriors, 161-90 on nineteenth-century American sailors.

57 "Man of Sand'. In "Awful Arizona" Holliday seemed to imply that Sheriff John Behan's “woman" was a prostitute and that Holliday was her customer.

${ }^{58}$ Benemann, Male-Male Intimacy in Early America, 16.

${ }^{59}$ On historical forms of same-sex intimacy that do not resemble modern homosexuality, see Halperin, How To, 38; 132.

${ }^{60}$ Hansen, “American Physicians,” 24; 16.

${ }^{61}$ Halberstam, Female Masculinity, 72. 
${ }^{62}$ Flynt, "Homosexuality,” 298. See Roberts, Doc Holliday, 208-9; 289; 351 and 386 for Holliday’s periods in jail.

${ }^{63}$ Leadville Carbonate Chronicle, June 16, 1913, states Lomeister married in 1889.

${ }^{64}$ Ellis, Sexual Inversion, 192.

${ }^{65}$ Ellis, Sexual Inversion, 192; Blumer, "Perverted Sexual Instinct," 23-25, quoted in Hansen,

“American Physicians," 15.

66 “Awful Arizona'.

67 'Leadville Sketches'.

68 "Famous Gun Man,” Kansas City Journal, January 16, 1899; “Doc Holliday’s Ways: One of Them Was Always to Wear a Boiled Shirt,” Evening Star, January 18, 1896.

${ }^{69}$ Cowen, "Happy Bad Men’.

${ }^{70}$ Cowen, "Happy Bad Men”; Hansen, “American Physicians," 16.

${ }^{71}$ See Wyatt-Brown, Southern Honor, 166-7; 156.

${ }^{72}$ In an apocryphal tale Holliday might have enjoyed - "He Was Left Handed" (repr. from New York Sun), Castle Rock Journal, April 23, 1884 - a "little dandy" with "a voice as soft as a woman's" defends himself by punching a bully with his "dainty little fist like a bullet'. This dandy is camp and affected, but no allusions are made to his sexual preferences whatsoever. History's most perfect dandy, George Bryan "Beau" Brummell (1778-1840), seems to have been too enamored of himself to desire anyone else of either sex. See Moers, Dandy, 36-37.

${ }^{73}$ See Isenberg, "Code," 153 , on this binary characterization from Masterson.

${ }^{74}$ Ellis, Sexual Inversion, 192-93.

${ }^{75}$ Rotundo, American Manhood, 277; Halperin, How To, 132.

${ }^{76}$ Lawrence and Garner v. Texas, 7. Apparently prosecutions for sodomy in private between consenting adult males (as opposed to abuse of minors) were infrequent, but was this because communities tolerated such activities (see Benemann, Male-Male Intimacy, 16), or because evidence of such acts was almost impossible to procure (see Lawrence and Garner v. Texas, 9)?

${ }^{77}$ New York Times, March 26, 1885.

${ }^{78}$ Toronto Mail, November 14, 1890, in Gowers, Swamp of Death, 361.

${ }^{79}$ Rotundo, American Manhood, 86-87.

${ }^{80}$ Isenberg, "Code," 157-57. 
${ }^{81}$ See “Old January's Last Days,” New York Times, November 16, 1887 for a gambler giving a public statement about their values and commitments.

${ }^{82}$ Stott, Jolly Fellows, 230.

${ }^{83}$ Leadville Democrat, August 20, 1884, repr. in Griswold and Griswold, History of Leadville, 1494. Isenberg, "Code," 151, demonstrates that Earp probably shared a bed with fellow policeman Jimmy Cairns in 1875-76.

${ }^{84}$ Leadville Daily Democrat, December 21, 1884.

${ }^{85}$ Carbonate Chronicle, August 27, 1884, in Griswold, History of Leadville, 1497.

86 "Holliday’s Trail of Blood"; "Local Laconics," Leadville Daily and Evening Chronicle, November $10,1887$.

${ }^{87}$ Rotundo, American Manhood, 91, In Lomeister's case, the shift from saloon to club probably also mirrors the closing of the frontier and its lawless bachelor ways.

${ }^{88}$ Leadville Herald Democrat, December 7, 1894; November 17, 1895.

${ }^{89}$ See www.pythias.org/about/pythstory.html (accessed August 10, 2012). Isenberg, "Code," discusses this organization (founded in 1864) in some detail.

${ }^{90}$ Courtwright, Violent Land, 82; 97. In "Awful Arizona," Holliday claimed to have seen twenty-four men lynched at once in Fort Griffin.

91 “Doc Holliday,” Pueblo Chieftain, May 17, 1882.

${ }^{92}$ Leadville Democrat, August 20, 1884, in Griswold, History of Leadville, 1495.

93 “Leadville Sketches'.

94 “Awful Arizona’.

${ }^{95}$ Cowen, “Happy Bad Men’.

96 “Talks About Tubercles,” Buena Vista Democrat, May 19, 1886.

${ }^{97}$ Description drawn from Davies, "Respiratory Tuberculosis," and Clark, Treatise on Pulmonary Consumption.

98 "Talks About Tubercles”; “Awful Arizona'.

99 "Beaten by Yuma Thugs," San Francisco Call, December 18, 1895, reports that a consumptive in Arizona confronted two gamblers who had defrauded him of his savings: they beat him savagely and he died two days later.

${ }^{100}$ Squire, Hygienic Prevention, 189. 
101 “Awful Arizona”; “Murderer’s Methods," Denver Daily Tribune, May 16, 1882; Arizona Daily

Star; "Death of J.A. Holliday'.

102 “Holliday Bound Over," Leadville Daily Herald, August 26, 1884.

${ }^{103}$ Roberts, Doc Holliday, 128.

${ }^{104}$ Leadville Democrat, August 20, 1884, in Griswold, History of Leadville, 1494.

${ }^{105}$ Obituary of Alice Jane Holliday by N. B. Ousley, September 1866, repr. in Pendleton and Thomas,

In Search of the Hollidays, 11. See Lawlor, Consumption and Literature, 35-38; 53-58.

${ }^{106}$ Holliday's reference to "pneumonia" suggests he understood the organic location of his disease, but I have found no contemporary source referring to his condition as 'tuberculosis'. See Mays, The Fly and Tuberculosis, and Rothman, Living in the Shadow of Death.

${ }^{107}$ This confusion was widespread: in 1886, "Talks about Tubercles" stated twice that "the bacillus" causing tuberculosis is "inherited."

${ }^{108}$ Bailin, Sickroom in Victorian Fiction, 22.

${ }^{109}$ Carbonate Chronicle, August 27, 1884, in Griswold, History of Leadville, 1497.

110 "Holliday Bound Over."

${ }^{111}$ Carbonate Chronicle, December 20, 1884, in Griswold, History of Leadville, 1607; "Man of Sand"; "Murderer's Methods".

112 "Holliday's Trail of Blood."

${ }^{113}$ Cowen, "Happy Bad Men”; Hansen, “American Physicians," 16.

${ }^{114}$ Holliday may have read “A Very Tough Man,” Rocky Mountain News, March 6, 1887, in which a bully shoots at a consumptive just to frighten him.

115 "Leadville Sketches”; “Death of J.A. Holliday”; “Holliday’s Trail of Blood”; “Murderer’s Methods"; “A Gritty Georgian.”

116 “Leadville Sketches"; Cowen, "Happy Bad Men”; "Death of J. A. Holliday”; “Death of Doc Holliday."

${ }^{117}$ In "Holliday Bound Over," two separate witnesses describe him as delicate. "Hopeful Holliday," Denver Rocky Mountain News, May 17, 1882, described him as "a delicate, gentlemanly man." 118 "Awful Arizona." It is possible the anonymous reporter was female, but it seems unlikely that a lady would be sent to interview an alleged mass-murderer in jail.

${ }^{119}$ I.e. Burg, Gay Warriors, and Flynt, "Homosexuality." 
${ }^{120}$ In Hamill, Doc, 165-66, Kate voices suspicions about Earp's erotic desire for Holliday very explicitly.

${ }^{121}$ See Halperin, How To, 3.

122 "Death of a Notorious Bunco Man”; “Doc Holliday,” St Joseph Herald, July 16, 1886.

123 "Death of Doc Holliday."

\section{References}

Badon, Ellis T. “Butch.” “An Unexpected Nugget.” NOLA Quarterly 25 (2001): 21-25.

Bailin, Miriam The Sickroom in Victorian Fiction: The Art of Being Ill. Cambridge: Cambridge University Press, 1994.

Benemann, William. Male-Male Intimacy in Early America: Beyond Romantic Friendships. New York: Harrington Press, 2006.

Blake, Michael F. Hollywood and the OK Corral: Portrayals of the Gunfight and Wyatt Earp. Jefferson, NC: McFarland, 2007.

Blumer, G. Alder. “A Case of Perverted Sexual Instinct (Conträre Sexualempfindung)., American Journal of Insanity 39, (1882): 22-35.

Bork, A. W. and Glenn Boyer, eds. "Mary Cummings' Statement: the OK Corral Fight at Tombstone: a Footnote by Kate Elder." Arizona and the West, 19, no. 1 (1977): 65-84 .

Burg, B. R. Gay Warriors: a Documentary History from the Ancient World to the Present. New York: New York University Press, 2002.

Burns, Walter Noble. Tombstone: an Iliad of the Southwest. 1927. Reprint, New York: Doubleday \& Company, 1994.

Clark, James. A Treatise on Pulmonary Consumption. London: Sherwood Gilbert and Piper, 1835.

Courtwright, David T. Violent Land: Single Men and Social Disorder from the Frontier to the Inner City. Cambridge, MA: Harvard University Press, 1996.

Davies, Peter D. O. "Respiratory Tuberculosis." In Clinical Tuberculosis, Edited by Peter D. O.. Davies, $3^{\text {rd }}$ edn. London: Arnold, 2003.

Earp, Josephine. Wyatt's Woman: She Married Wyatt Earp. Edited by Earl Chafin. Riverside, CA: Earl Chafin Press, 1998. 
Earp, Wyatt. Wyatt Earp Speaks! My Side of the OK Corral Shootout, Plus Interviews with Doc Holliday. Edited by. John Richard Stephens (Cambrian Pines by the Sea: Fern Canyon Press, 1998.

Ellis, Havelock, and John Addington Symmonds. Sexual Inversion. 1897. Reprint, edited by Ivan Crozier, Houndmills, Basingstoke: Palgrave Macmillan, 2008.

Faragher , John Mack. "The Tale of Wyatt Earp: Seven Films.” In Past Imperfect: History According to the Movies, edited by Ted Mico, John Miller-Monzon, and David Rubel, 154-161. London: Cassel, 1995.

Fejes, Fred. Gay Rights and Moral Panic: the Origins of America's Debate on Homosexuality. New York: Palgrave Macmillan, 2008.

Flynt, Josiah. "Homosexuality Among Tramps" (1897). Appendix B in Ellis, Sexual Inversion.

Gowers, Rebecca. The Swamp of Death: a True Tale of Victorian Lies and Murder. London: Hamish Hamilton, 2004.

Griswold, Don L. and Jean Harvey Griswold. History of Leadville and Lake County, Colorado. Boulder, CO: Colorado Historical Society/ University of Colorado Press, 1996.

Guinn, Jeff. The Last Gunfight: the Real Story of the Gunfight at the OK Corral - and How it Changed the American West. London: Robson Press, 2011.

Halberstam, Judith. Female Masculinity. Durham, NC and London: Duke University Press, 1998.

Halperin, David M. How To Do the History of Homosexuality. Chicago: University of Chicago Press, 2002.

Hamill, Peter. Doc: the Original Screenplay. New York: Paperback Library, 1971.

Hansen, Bert “American Physicians' 'Discovery' of Homosexuals, 1880-1900: a New Diagnosis in a Changing Society." In Sickness and Health in America: Readings in the History of Medicine and Public Health, edited by Judith Walter Leavitt and Ronald L. Numbers, $3^{\text {rd }}$ edn. Madison: University of Wisconsin Press, 1997.

Herda, D. J. They Call Me Doc: the Story Behind the Legend of Doc Holliday. Kindle edition. Guilford, CT: Lyons Press, 2011.

Isenberg, Andrew C. "The Code of the West: Sexuality, Homosociality, and Wyatt Earp." Western Historical Quarterly 40, no. 2 (Summer 2009): 139-157. 
Jahns, Pat. The Frontier World of Doc Holliday. 1957. Reprint, Lincoln: University of Nebraska Press, 1998.

Lake, Stuart N. Wyatt Earp: Frontier Marshal. 1931. Reprint, London: Pocket Books, 1994.

Lawlor, Clark. Consumption and Literature: the Making of the Romantic Disease. Houndmills, Basingstoke, UK: Palgrave Macmillan, 2006.

Masterson, W.B. "Bat." "Doc Holliday" (1907), 36-38. Reprinted in Masterson, Famous Gunfighters of the Western Frontier: Wyatt Earp, Doc Holliday, Luke Short and Others. 1957. Reprint, New York: Dover Publications, 2009.

Mays, Thomas J. The Fly and Tuberculosis. New York: A.R. Elliot Publishing, 1905.

Moers, Ellen. The Dandy: Brummell to Beerbohm. Lincoln: University of Nebraska Press, 1978.

Myers, John Myers. Doc Holliday. Lincoln: University of Nebraska Press, 1973.

Packard, Chris. Queer Cowboys, and Other Erotic Friendships in Nineteenth-Century American Literature. New York: Palgrave Macmillan, 2005.

Pendleton, Albert S. and Susan McKey Thomas. In Search of the Hollidays: the Story of Doc Holliday and his Holliday and McKey Families. Valdosta, GA: Little River Press, 1973.

Roberts, Gary "Brothers of the Gun.” Wild West 25, no. 4 (December 2012): 28-35.

Roberts, Gary. Doc Holliday: the Life and Legend. Hoboken, NJ: John Wiley and Sons, 2006.

Rothman, Sheila M. Living in the Shadow of Death: Tuberculosis and the Social Experience of Illness in American History. Baltimore: John Hopkins University Press, 1995.

Rotundo, E. Anthony. American Manhood: Transformations of Masculinity from the Revolution to the Modern Era. New York: Basic Books, 1993.

Squire, J. Edward. The Hygienic Prevention of Consumption. London: Charles Griffin, 1893.

Stewart-Winter, Timothy and Simon Stern. "Picturing Same-Sex Marriage in the Antebellum United States: the Union of 'Two most Excellent Men' in Longstreet's 'A Sage Conversation.”' Journal of the History of Sexuality 19, no. 2 (May 2010): 197-222.

Stott, Richard Jolly Fellows: Male Milieus in Nineteenth-Century America. Baltimore: Johns Hopkins University Press, 2009.

Tefertiller, Casey. Wyatt Earp: the Life Behind the Legend. New York: John Wiley \& Sons, 1997.

Traywick, Ben T. John Henry: the "Doc” Holliday Story. Tombstone, AZ.: Red Marie's Bookstore, 1996. 
Wyatt-Brown, Bertram. Southern Honor: Ethics and Behavior in the Old South. Oxford: Oxford University Press, 1982. 